Studia nad Autorytaryzmem i Totalitaryzmem 43, nr 3

Wrocław 2021

https://doi.org/10.19195/2300-7249.43.3.17

JACEK SROKOSZ

ORCID: 0000-0002-7587-6483

Uniwersytet Opolski

jsrokosz@uni.opole.pl

\title{
Autorytarna merytokracja — zarys modelu i jego legitymizacja na przykładzie Chin
}

Słowa kluczowe: autorytaryzm, merytokracja, prawo, Chiny, legitymacja.

\author{
AUTHORITARIAN MERITOCRACY: AN OUTLINE OF THE MODEL \\ AND ITS LEGITIMISATION ON THE EXAMPLE OF CHINA
}

\begin{abstract}
The article analyses the model of authoritarian meritocracy and its legitimisation on the example of the Chinese People's Republic. The discussed model is based on three principles: 1. power is exercised by a monoparticle elite that legitimises its position on the basis of moral and substantive criteria; 2. patriarchal and anti-democratic governance; 3 . the authorities' policy aims to meet the material needs of citizens, but without granting them political rights. The Communist Party of China in its official narrative, on the one hand, refers to the assumptions of Maoism, but on the other hand, to a much greater extent - especially in the field of economic cases and the operation of the administrative apparatus - to the Confucian tradition. The model of authoritarian meritocracy in China should be treated as an ongoing experiment, whose final shape has a much more local nature than universal one, which it tries to claim. Nevertheless, the economic success and rapid modernization progress of the "Central State" undermined the theses formulated in the West after 1989 that economic development must be accompanied by the implementation of liberal democracy principles. For this reason, the Chinese authoritarian meritocracy may be perceived as a real alternative to the existing hegemonic vision of the West - the need to combine a free market economy with political freedoms and autonomy of individuals.
\end{abstract}

Keywords: authoritarianism, meritocracy, law, China, legitimisation. 
Transformacje ustrojowe państw realnego socjalizmu oraz rozpad Związku Radzieckiego w ostatniej dekadzie XX wieku w zachodnim dyskursie politycznym i prawnym zostały przyjęte jako zapowiedź triumfu zachodniego modelu ustroju politycznego, społecznego i gospodarczego. Najdonioślejszym przykładem przekonania, które niemal na trzy dekady opanowało myślenie Zachodu, jest słynna teza amerykańskiego politologa Francisa Fukuyamy o „końcu historii”, rozumianym jako ostateczne zwycięstwo demokracji liberalnej połączonej z gospodarką wolnorynkową nad innymi konkurencyjnymi projektami polityczno-społecznymi wypracowanymi po epoce oświecenia ${ }^{1}$. Dość optymistycznie przyjmowano, że te nieliczne państwa, w których władzę utrzymały partie komunistyczne, a także te do tej pory próbujące „trzeciej drogi” między socjalizmem a demokracją liberalną, prędzej czy później będą musiały zaimplementować zwycięski model zachodni - ponieważ tylko on pozostał jako jedyna realna oferta na stole. Po trzech dekadach absolutnej hegemonii tego przekonania okazało się jednak - na co wskazuje coraz więcej badaczy i analityków - że na polu ideologicznym i gospodarczym pojawiła się realna konkurencja dla zachodniego modelu ustrojowego - model chiński. Celem tego opracowania jest przedstawienie zarysu modelu chińskiej autorytarnej merytokracji oraz sposobu jego legitymizowania, jako potencjalnej alternatywnej propozycji dla zachodniej demokracji liberalnej jako ustroju politycznego oraz gospodarczego. Przedmiotem analizy nie będzie jednak praktyka funkcjonowania Komunistycznej Partii Chin (KPCh) oraz instytucji państwa chińskiego, która czasami jest biegunowo odległa od oficjalnych deklaracji władz Chińskiej Republiki Ludowej (ChRL), lecz rekonstrukcja modelu ustrojowego na podstawie oficjalnej narracji i doktryn głoszonych przez władze ${ }^{2}$.

Pojęcie merytokracji dosyć chętnie używane jest we współczesnych naukach społecznych, najczęściej pojawia się w dyskursie socjologicznym, choć bywa obecne także w dyskursie prawniczym ${ }^{3}$. Najogólniej można określić merytokrację jako postulat przebudowy życia społecznego i politycznego w kierunku systemu, w którym miejsce jednostki w hierarchii społecznej będzie uzależnione od obiektywnie weryfikowalnych i potwierdzonych kompetencji, a władza nad pewnymi obszarami życia społecznego zostanie powierzona osobom legitymującym się obiektywną i fachową wiedzą z tego zakresu. Samo pojęcie pochodzi

${ }^{1}$ F. Fukuyama, The End of History, „The National Interest” 1989, nr 16, s. 3-18; rozszerzona wersja: idem, The End of History and The Last Man, New York 1992.

2 Praktyka funkcjonowania KPCh oraz jej relacje $\mathrm{z}$ administracją państwową przedstawia raport Ośrodka Studiów Wschodnich: M. Bogusz, J. Jakubowski, Komunistyczna Partia Chin i jej państwo. Konserwatywny zwrot Xi Jinpinga, Warszawa 2019.

${ }^{3} \mathrm{~W}$ dyskursie prawniczym najczęściej pojawia się przy problematyce legitymacji władzy sądowniczej i pozycji prawników we współczesnym społeczeństwie — w szczególności sędziów. Więcej na temat definiowania pojęcia merytokracji zob. C.H. Kim, Y.B. Choi, How meritocracy is defined today?: Contemporary aspects of meritocracy, „Economics and Sociology” 10, 2017, nr 1, s. $112-121$. 
od zbitki dwóch słów: łacińskiego 'mereō' oznaczającego zasługi ('merit') z oraz greckiego przyrostka 'kratos' oznaczającego władzę czy rządy.

Do dyskursu publicznego pojęcie merytokracji zostało wprowadzone przez brytyjskiego socjologa Micheala Younga w wydanej w 1958 roku dystopii The Rise of Meritocracy. 1870-20334. Autor w swoim dziele przedstawił pesymistyczną wizję przeobrażania się struktur brytyjskiego systemu społecznego i politycznego z klasowego z przewagą arystokracji w kierunku wyobrażonego merytokratycznego - w tym ostatnim władzę sprawować miała nowa klasa wyłoniona z wykorzystaniem obiektywnych fachowych kryteriów. Zmiana ta podyktowana miała być koniecznością zapewnienia efektywnego i sprawnego zarządzania gospodarką oraz życiem społecznym, przez lepsze wykorzystywanie zasobów ludzkich. Istotą zmian było stworzenie mechanizmu awansu społecznego opartego na kryteriach potencjału intelektualnego oraz pracy jednostki włożonej w podnoszenie swoich kwalifikacji. Efektem przemian miało być pojawienie się nowej fachowej elity, wprawdzie mającej najwyższe kwalifikacje do maksymalnie optymalnego zarządzania życiem państwa i społeczeństwa, jednak pozbawionej kręgosłupa moralnego, egoistycznej, odizolowanej od społeczeństwa oraz dążącej do zamknięcia się przed dopływem nowych jednostek i jednocześnie pogardzającej klasami niższymi.

Sama idea sprawowania rządów przez osoby najbardziej wykwalifikowane nie była rzecz jasna pomysłem Younga. Pojawiła się ona już w starożytności w podobnym czasie w dwóch miejscach na świecie - w Grecji i Chinach. Na Półwyspie Peloponeskim idea ta najpełniej została wyrażona przez Platona w jego koncepcji powierzenia władzy nad społeczeństwem uprzywilejowanym intelektualnie względem innych osób królom-filozofom. Chociaż Platon próbował przekonywać współczesnych mu władców greckich państw-miast do realizacji jego idei, to w praktyce nie wyszły one poza sferę postulatów. Taki też charakter miały propozycje merytokratyczne myślicieli nowożytności na Zachodzie, począwszy od Oświecenia po czasy współczesne ${ }^{5}$. W kręgu cywilizacji Zachodu narracja odwołująca się do merytokracji pozostaje niezwykle istotna i bardzo często pojawia się w dyskursie publicznym, zwłaszcza w zakresie legitymowania pozycji ustrojowej i władzy sądownictwa czy też służby cywilnej jako tych segmentów władzy, które powinny pozostawać poza bezpośrednią demokratyczną kontrolą ludu ${ }^{6}$. Niemniej rzadko pojawiają się propozycje wprowadzania rozwiązań politycznych opartych na cenzusie intelektu czy kompetencji — a jeśli już takie zostają sformułowane,

${ }^{4}$ M. Young, The Rise of Meritocracy: 1870-2033, Harmondworth 1958.

5 Propozycje te przybierały zazwyczaj formę technokratyzmu lub menedżeryzmu - można je traktować jako pewne odnogi ogólnej ideologii merytokratycznej, gdyż kryterium uzyskiwania i sprawowania władzy były fachowe umiejętności, tyle że ograniczone do zarządzania gospodarką przemysłową. Zob. J. Kurczewska, Technokraci i ich świat spoteczny, Warszawa 1997.

${ }^{6}$ D.A. Bell, The China Model. Political Meritocracy and the Limits of Democracy, New Jersey 2016, s. 4, 27. 
to traktowane są raczej jako pewien koloryt niż realna opcja ustrojowa. Merytokracja w świecie Zachodu pozostaje więc tylko swoistym rodzajem soft power, odgrywając olbrzymią rolę $\mathrm{w}$ dyskursie publicznym, niemniej nie przekłada się zazwyczaj na rozwiązania ustrojowe.

Odmiennie potoczyły się losy projektów merytokratycznych w Chinach począwszy od starożytności, zostały one wdrożone do rzeczywistości społecznej i niewątpliwie dostarczyły inspiracji kierownictwu KPCh w zakresie kierunku reformowania państwa po zakończeniu epoki Mao Zedonga. Decydującą rolę w stworzeniu idei merytokracji odegrał Konfucjusz i jego projekt filozoficzny, który należy krótko czytelnikowi przybliżyć ${ }^{7}$. Podstawą założeń filozoficznych Konfucjusza było przekonanie o obiektywnym istnieniu porządku, hierarchii i harmonii panujących zarówno w świecie przyrody, jak i w społeczeństwie ludzkim. Z tych prawidłowości w życiu społecznym wynikał obowiązek podporządkowania się osobom znajdującym się na jej wyższym szczeblu hierarchii i dotyczył wszystkich relacji społecznych - począwszy od rodzinnych, na relacjach poddanych z władzą skończywszy. Dopiero gdy istniał i był przestrzegany ten naturalny porządek, a każdy wykonywał przynależne mu zadania, można było mówić o harmonijnie funkcjonującym państwie ${ }^{8}$.

Według Konfucjusza na każdym człowieku spoczywał też obowiązek praktykowania cnoty i doskonalenia się moralnego, jednak nie wszyscy byli w jednakowym stopniu obdarzeni zmysłem etycznym - według niego mieli go w różnym stopniu ludzie szlachetni, prostacy zaś byli go pozbawieni. Wymóg stałego doskonalenia natury ludzkiej, a co za tym idzie także całego społeczeństwa i państwa, był możliwy tylko wtedy, gdy spoczywała w rękach osób najszlachetniejszych, przy czym arystokratyczna pozycja miała się opierać nie na więzach rodzinnych, lecz na przymiotach osobistych jednostki - wiedzy, uczciwości i cnocie. Zatem w hierarchii państwowej osoby najszlachetniejsze duchowo powinny zajmować wyższe pozycje, nawet jeśli pochodziłyby z uboższych warstw społecznych.

Idealistyczne postulaty Konfucjusza były twórczo rozwijane przez jego uczniów — takich jak Mencjusz i Xunzi ${ }^{9}$ - i w przeciwieństwie do postulatów platońskich znalazły swoje odbicie w rzeczywistości społecznej pod postacią konkretnych rozwiązań ustrojowych. Praktycznym ucieleśnieniem tych idei stał się wprowadzony od dynastii Han system obsadzania stanowisk w administracji państwowej na podstawie egzaminów na stanowiska urzędnicze ${ }^{10}$. W trakcie

7 Więcej na temat konfucjanizmu zob. A.I. Wójcik, Konfucjusz, Kraków 1995; X. Yao, Konfucjanizm. Wprowadzenie, Kraków 2009; R. Sławiński, Konfucjanizm i jego współczesne interpretacje, Warszawa 2013.

8 Więcej na temat państwa w myśli Konfucjusza zob. K. Gawlikowski, Konfucjański model państwa w Chinach, Warszawa 2009.

9 Obszerniej M. Religa, Mencjusz i Xunzi. O dobrym władcy, mędrcach i naturze ludzkiej, Warszawa 1999.

${ }^{10} \mathrm{O}$ imperialnym systemie egzaminacyjnym więcej B.A. Elman, A Cultural History of Civil Examinations in Late Imperial China, Berkeley 2000. 
egzaminów od kandydatów wymagano przede wszystkim znajomości pism Konfucjusza, ale także innych chińskich filozofów, odnoszących się nie tylko do strony moralnej człowieka, lecz także do praktycznych rytuałów, sposobów zachowania, a nawet literatury pięknej. Kandydat na urzędnika powinien być zatem wszechstronnie wykształcony i w razie pozytywnej opinii egzaminatorów mógł objąć stanowisko w administracji państwowej. Administracja cesarska była bardzo zhierarchizowana i oparta na zasadzie bezwzględnego podporządkowania urzędnika przełożonym oraz niższych szczebli szczeblom wyższym. Awans na wyższy szczebel wymagał zdania kolejnych egzaminów i dobrej oceny przez przełożonego nie tylko dotychczasowej pracy, lecz także zachowania się $\mathrm{w}$ sferze prywatnej. Wymogi te sprawiać miały, że to osobiste przymioty, a nie kryterium urodzenia będzie decydującym czynnikiem w obsadzaniu administracji publicznej. $\mathrm{W}$ toku funkcjonowania tego systemu egzaminacyjnego zmniejszano lub rozszerzano dostęp do niego osób spoza lokalnej arystokracji, lecz zawsze istniała możliwość dostępu do służby publicznej dla osób pochodzących z niższych warstw społecznych ${ }^{11}$. System egzaminów urzędniczych został zniesiony w 1912 roku wraz z upadkiem cesarstwa - uznano go za anachroniczny i uniemożliwiający budowę nowoczesnego państwa.

Drugą — współczesną — inspiracją chińskiej autorytarnej merytokracji stało się inne państwo azjatyckie - Singapur ${ }^{12}$. Począwszy od uzyskania niepodległości w latach sześćdziesiątych XX wieku, polityczni liderzy azjatyckiego państewka z Lee Kuan Yewem na czele zdecydowali się wprowadzić instrumenty o charakterze merytokratcznym, kosztem instytucji demokratycznych. Uzasadniano to koniecznością sprawnego zarządzania państwem zagrożonym stale ze strony większych sąsiadów, mającym niewielkie zasoby naturalne oraz niewielką liczbę ludności. Aby trwanie i dobrobyt małego państwa-miasta był możliwy, władzę musiały sprawować osoby kompetentne, mające wiedzę oraz wizję długofalowego rozwoju ${ }^{13}$. Nie sprzyjały temu cykle wyborcze i walka partyjna skutkująca

11 System egzaminacyjny pełnił pozytywną funkcję w kwestii stabilności cesarstwa. Po pierwsze, pozwalał na fachowe obsadzanie administracji mogącej realizować wielkie zadania, takie jak zapobieganie powodziom czy też budowa Wielkiego Muru. Po drugie, pozwalał cesarzowi temperować zapędy arystokracji, promując ludzi zależnych od władcy. Wreszcie po trzecie, był on swego rodzaju narzędziem dystrybucji prestiżu, gdyż osoby, które nie zdawały egzaminów, i tak uzyskiwały wysoki status społeczny, wykonując zawody lekarzy, nauczycieli, kupców czy prawników. B.A. Elman, A Society in Motion: Unexpected consequences of political meritocracy in Late Imperial China, 1400-1900, [w:] The East Asian Challenge for Democracy. Political Meritocracy in Comparative Perspective, red. D.A. Bell, Ch. Li, New York 2013, s. 203-231.

12 Więcej na temat funkcjonowania merytokracji w Singapurze zob. B. Wong, Political meritocracy in Singapore: Lessons from the PAP Government, [w:] The East Asian Challenge..., s. 288-313; K.P. Tan, Meritocracy and political liberalization in Singapore, [w:] The East Asian Challenge..., s. 314-339; idem, Meritocracy and elitism in a Global City: Ideological shifts in Singapore, „International Political Science Review” 29, 2008, s. 7-27.

13 H.F. Kwang, W. Fernandez, S. Tan, Lee Kuan Yew: The Man and His Ideas, Singapore 1998, s. 315. 
trwonieniem sił i środków na konieczność rywalizacji politycznej. Realizacją tych założeń był autorytarny reżim stworzony przez wspomnianego Lee Kuan Yewa, w którym wprawdzie odbywają się regularne wybory, lecz władzę od uzyskania niepodległości dzierży nieprzerwanie jedna partia - Partia Akcji Ludowej, natomiast swobody obywatelskie, takie jak wolność słowa czy zgromadzeń, są znacząco ograniczone. Stanowiska w administracji państwowej obsadzane są według kryterium fachowości, na podstawie egzaminów oraz formalnego wykształcenia uniwersyteckiego. W oficjalnej narracji władz Singapuru każdy obywatel ma możliwość zdobycia stanowiska w aparacie państwowym — zależne jest to od jego talentów, wykształcenia oraz ciężkiej pracy.

Zgodnie ze słowami Lee Hsien Loonga, syna Lee Kuan Yewa, system stworzony w Singapurze, w którym władza wybrana na podstawie obiektywnych kryteriów działa w interesie i z szacunkiem dla obywatela, jest lepszy niż zachodni, w którym obywatel władzy nie ufa, a system oparty jest na jak największym ograniczeniu zakresu działania rządzącym ${ }^{14}$. Co więcej, według autora w zarządzaniu państwem lepiej sprawdza się system patriarchalny niż demokratyczny. Korzystniej dla wszystkich jest bowiem powierzenie władzy osobom najbardziej kompetentnym, gdyż tylko one potrafią myśleć długofalowo oraz kreślić śmiałe plany rozwoju, natomiast powierzenie decyzji co do losów państwa mało refleksyjnemu ludowi jest niedorzeczne. Dla zwolenników systemu merytokracji politycznej przykład oszałamiającego sukcesu gospodarczego oraz tempo rozwoju Singapuru jest dowodem na słuszność tez liderów Partii Akcji Ludowej.

Tym tokiem rozumowania podążyli też przywódcy chińscy — w szczególności uważany za wizjonera i ojca współczesnego sukcesu gospodarczego Państwa Środka Deng Xiaoping — którzy po śmierci Mao i obaleniu władzy „Bandy Czworga" u schyłku lat siedemdziesiątych XX wieku zdecydowali się na stopniowy odwrót od ideologii komunistycznej oraz celu państwa, jakim miało być rozszerzenie rewolucji proletariackiej. Nowa ekipa za cel postawiła sobie budowę nowoczesnego państwa, gwarantującego dobrobyt swoim obywatelom, a w dalszej kolejności stającego się mocarstwem światowym. Wprawdzie władze oficjalnie zachowały linię ideologiczną Mao, lecz w praktyce, zwłaszcza po 1989 roku, stała się ona bardziej pustą formą przykrywającą realne procesy zachodzące w partii i państwie niż ideologią realnie kierującą poczynaniami władz. Od końca lat siedemdziesiątych rozpoczął się proces poszukiwania innej drogi gospodarczej, sposobu funkcjonowania organów państwowych oraz samej treści ideologii legitymującej władzę partii komunistycznej, przy założeniu niezmienności formalnych ram ustrojowych państwa. W toku kilkudziesięciu lat eksperymentów gospodarczych oraz zmian praktyki funkcjonowania organów państwowych ukształtował się system, który można określić jako autorytarną merytokrację,

14 E. Lee, Singapore: The Unexpected Nation, Singapore 2008, s. 547. 
choć w literaturze pojawia się określenie polityczna merytokracja ${ }^{15}$. Systemu chińskiego nie można uznać za skończony projekt, lecz bardziej jako pewien trwający eksperyment - jako system znajdujący się w transformacji. Niemniej jednak wydaje się, że można nakreślić pewien zarys charakteryzujący model chińskiej autorytarnej merytokracji.

Według koreańskiego badacza Doll Chull Shina azjatycka koncepcja merytokracji opiera się na trzech założeniach: 1 . władza sprawowana jest przez elitę wyłonioną na podstawie cnót moralnych oraz zdolności merytorycznych, 2. władza ma charakter patriarchalny — zwykły obywatel nie ma wpływu na decyzję rządzących, gdyż pojmowanie złożoności spraw publicznych przekracza jego zdolności poznawcze, 3. rządzący muszą zapewnić dobrobyt ludowi, gdyż moralne postępowanie jednostki jest zapewnione, gdy zostaną zaspokojone jej podstawowe potrzeby ${ }^{16}$. Wszystkie te elementy można odnaleźć w systemie politycznym oraz w oficjalnej narracji partii rządzącej w Chinach.

System autorytarnej merytokracji opiera się na odrzuceniu zasad demokracji rozumianej w zachodni sposób, jako systemu politycznego gwarantującego każdej jednostce udział w sprawowaniu władzy, opartego na zasadzie równej wagi głosu każdego obywatela, a także nieograniczonej konkurencji ugrupowań politycznych w walce o władzę. System polityczny oparty na zachodnich wartościach ma być zaprzeczeniem azjatyckich wartości i nieść konieczność implementowania sprzecznej z nimi wizji świata. Przede wszystkim prowadzić ma do nieograniczonej walki politycznej między partiami, niszczącej ład i harmonię społeczną, pozbawia rządzących możliwości realizowania długofalowej polityki i przez okresowe kampanie wyborcze zmusza do spełniania zachcianek wyborców, zwykle nierozumiejących w należytym stopniu spraw państwowych. Stwarza zatem pole do działania populistom ${ }^{17}$. Demokracja zachodnia jest uznawana za system nad wyraz nieefektywny w działaniu, gdyż podjęcie każdej decyzji zajmuje zbyt wiele czasu, a po wyborach nowa ekipa może realizować zupełnie odmienny program polityczny w stosunku do programu poprzedników. Wreszcie opierać się ma na fałszywym założeniu o równej kondycji intelektualnej wszystkich obywateli, skoro konsekwencją tego jest przyznanie każdemu takiej samej wagi głosu w sprawach publicznych.

Odrzucając zachodni model demokracji, zwykle proponuje się nowe rozumienie tego terminu, mające już w zamyśle autorów realizować azjatyckie wartości,

15 D.A. Bell, Introduction: The Theory, history, and practice of political meritocracy, [w:] The East Asian Challenge..., s. 1-30; idem, The China Model...

16 D.Ch. Shin, How East Asians view meritocracy: A Confucian perspective, [w:] The East Asian Challenge..., s. 267.

17 Zdaniem D. Bella siłą merytokracji miała być odporność na nurty populistyczne wstrząsające współczesnymi demokracjami Zachodu; idem, The China Model..., s. XXVI. Przeciwnego zdania są M. Chou, B. Moffit, O. Bryant, Political Meritocracy and Populism. Cure or Curse?, London 2019. 
takie jak hierarchia, harmonia, ład, wspólnotowość i prymat obowiązków jednostki wobec zbiorowości nad jej prawami ${ }^{18}$. Jak wskazuje Daniel Bell, w Chinach demokracji nadawane jest zupełnie inne znaczenie - jako działanie władzy na rzecz wszystkich obywateli w jednakowym stopniu, nie zaś dopuszczenie ich do sprawowania władzy ${ }^{19}$. Akcentowana jest zatem powinność władz realizacji dobra obywateli, ale bez ich udziału w określeniu, co mieści się pod tym pojęciem. Rządzący mają postępować wobec ludu w sposób patriarchalny, tak jak ojciec działający w interesie swoich dzieci - obywatel może domagać się równego prawa do korzystania z owoców pracy rządzących, nie zaś równego udziału w sprawowaniu rządów. Te ostanie powinny zostać powierzone osobom bardziej światłym, legitymującym się wyższym — i potwierdzonym oficjalnie — poziomem wiedzy, kwalifikacji oraz rozeznaniem spraw publicznych niż przeciętny obywatel. Zatem władza w państwie powinna zostać powierzona światłej oraz cechującej się wysokimi standardami etycznymi elicie, wśród której także musi istnieć hierarchia oparta na kryteriach merytorycznych i etycznych. Im większe kwalifikacje, wiedzę, doświadczenie oraz walory moralne ma jednostka, tym wyżej w hierarchii państwowej powinna się znaleźć — o jej awansie nie powinny decydować pokrewieństwo czy znajomości, lecz jedynie obiektywnie mierzalne kwalifikacje.

Już na pierwszy rzut oka widać w tej narracji odwołanie do tradycji konfucjańskiej oraz wynikającej z niej elitaryzmu i odejście od założeń maoistowskiego egalitaryzmu ${ }^{20}$. Jak wskazuje Bogdan Góralczyk, mimo rytualnego odwoływania się do ideologii komunizmu obecna narracja KPCh jest o wiele bardziej konfucjańska niż marksistowska ${ }^{21}$. Widocznym wyrazem praktycznego odrzucenia założeń maoistycznych było ponowne oparcie się rządzących na warstwie inteligenckiej, tak zwalczanej i poniżanej za rządów „Pierwszego Przewodniczącego”. Wyrazem tej reorientacji władz było między innymi przywrócenie w 1990 roku systemu obsadzania stanowisk w administracji państwowej na podstawie egzaminów oraz wymogu zdobycia przez kandydata wykształcenia uniwersyteckiego ${ }^{22}$. Objęcie zarządu państwem, w szczególności gospodarką, przez kompetentne osoby było niezbędne do zrealizowania przyjętych celów partii rządzącej — dla wielu członków KPCh stało się to oczywiste po doświadczeniach „Wielkiego Skoku” oraz

18 Bardziej „azjatyckie wartości” omawia D. Hitchcock, Asian Values and the United States: How Much Conflict?, Washington 1994; S.Y. Kim, Do Asian values exist? Empirical tests of the four dimensions of Asian values, „Journal of East Asian Studies” 10, 2010, nr 2, s. 315-344.

19 D.A. Bell, The China Model..., s. 138.

${ }^{20}$ O renesansie konfucjanizmu w Chinach zob. D.A. Bell, China's New Confucianism: Politics and Everyday Life in a Changing Society, Princeton-Oxford 2010; R. Fan, Confucian meritocracy for contemporary China, [w:] The East Asian Challenge ..., s. 88-115.

21 B. Góralczyk, Wielki renesans. Chińska transformacja i jej konsekwencje, Warszawa 2018, s. 209 n. Zob. też D. Zhao, The Confucian-legalist State: A New Theory of Chinese History, Oxford 2015.

22 Zob. H. Xiao, Ch. Li, China's meritocratic examinations and the ideal of virtuous talents, [w:] The East Asian Challenge..., s. 340-362. 
„rewolucji kulturalnej”. Decydującym kryterium obsadzania stanowisk miało być od tej pory nie zaangażowanie rewolucyjne, lecz obiektywnie mierzone kwalifikacje.

Formalnie podstawowe założenia ustrojowe ChRL się nie zmieniły — władzę sprawuje monopartia, obywatele nie uzyskali rozszerzenia praw politycznych - a co więcej, w okresie sprawowania władzy przez Xi Jinpinga inwigilacja oraz kontrola ze strony władz zdecydowanie wzrasta. Wyczekiwane przez chińskich dysydentów oraz polityków państw Zachodu zmiany mające doprowadzić do większej demokratyzacji Chin nie nastąpiły i wydaje się, że raczej szybko nie nastąpią. Niemniej jednak aspekt merytokratyczny widoczny jest także w wprowadzonych zmianach w funkcjonowaniu KPCh w czasie sprawowania władzy przez Deng Xiaopinga, który obawiając się powrotu kultu jednostki z czasów Mao, zdecydował się na stopniowe wprowadzanie zbiorowego kierownictwa w partii. Wprawdzie dominującą pozycję jako primus inter pares zachował I sekretarz KPCh, który jest jednocześnie głową państwa (przewodniczący ChRL) oraz naczelnym dowódcą, ale nie dysponuje pełnią władzy w państwie. Dzieli ją z ,głównym wykonawcą" - premierem odpowiedzialnym za sprawy gospodarcze i administrowaniem państwa oraz siedmioosobowym Komitetem Stałym Biura Politycznego KC KPCh, określanego przez Bogdana Góralczyka „zbiorowym cesarzem"23. Droga do najwyższych stanowisk w państwie została obwarowana wieloma wymogami formalnymi - takimi jak konieczność wcześniejszego pełnienia określonej liczby kadencji funkcji kierowniczych na niższych szczeblach struktur państwowych. Ponadto wprowadzono zasadę ograniczonego czasu pełnienia najwyższych funkcji państwowych - maksymalnie dwie kadencje, a także ograniczenie wiekowe - do 68 roku życia ${ }^{24}$. Rozwiązania te mają zapewnić stałą rotację na szczycie piramidy władzy, a przez wymogi wcześniejszego doświadczania w kierowaniu strukturami państwa uniemożliwić błyskawiczne kariery faworytów aktualnie rządzących.

Skomplikowana pozostaje relacja partii z administracją państwową różnych szczebli. W czasach imperialnych rolą cesarza nie było bezpośrednie rządzenie i zajmowanie się bieżącymi sprawami, lecz panowanie — wyznaczanie ogólnych kierunków działań oraz priorytetów, które w życie wcielała administracja państwowa. Podobną funkcję ma pełnić KPCh, wyznaczająca drogi rozwoju państwa, natomiast realizowanie zadań wymagających wiedzy i odpowiednich kwalifikacji powierzone miało zostać czynnikowi fachowemu. Stąd też, podobnie jak w czasach cesarskich, administracja państwowa rekrutować się ma z osób z odpowiednim doświadczeniem, wiedzą oraz kwalifikacjami niezbędnymi do realizowania powierzonych zadań. Administracja zbudowana jest hierarchicznie i według ścisłego podporządkowania niższych szczebli wyższym, by móc szybko i skutecznie wdrażać plany i postanowienia zapadające w Biurze Politycznym KPCh. Awans

23 B. Góralczyk, op. cit., s. 195.

24 Ibidem, s. $195 \mathrm{n}$. 
w strukturach administracyjnych odbywa się na podstawie oficjalnych konkursów oraz ocen dokonywanych przez osoby znajdujące się wyżej w strukturze uwzględniane są osiągnięcia i doświadczenie. Formalnie każdy musi zaczynać od najniższych stanowisk w zarządzaniu małymi wsiami czy miasteczkami - nawet „książęta”, czyli dzieci partyjnych dygnitarzy ${ }^{25}$. W praktyce poziom partyjny i administracyjny się przenikają - zwłaszcza na wyższych szczeblach władzy stanowiska sprawują $\mathrm{w}$ praktyce wyłącznie członkowie partii ${ }^{26}$. Nie stworzono do tej pory przejrzystego systemu wzajemnych relacji między strukturami partyjnymi a aparatem administracyjnym.

Jedną z istotniejszych cech autorytarnej merytokracji jest sposób legitymowania rządzących. Jak już wskazano, w modelu tym odrzucono wolę ludu i wybór w procedurach demokratycznych jako podstawę mandatu do sprawowania władzy. Zamiast tego istotne sa cechy osobiste przypisywane przedstawicielom partii rządzącej. $Z$ jednej strony są to walory intelektualne, posiadana wiedza, formalnie potwierdzone wykształcenie oraz doświadczenie w kierowaniu sprawami państwa, począwszy od najniższego szczebla administracji. Wspomniane cechy mają gwarantować wysoki poziom refleksji rządzących, pozwalający im sięgać wzrokiem dalej niż zwykłemu obywatelowi, a tym samym uzasadniać konieczność podporządkowania się uprzywilejowanej poznawczo elicie. Jednakże, zgodnie z tradycją konfucjańską, rządy najlepszych oznaczają sprawowanie władzy nie tylko przez osoby najbardziej wykwalifikowane, lecz także osoby najbardziej etyczne i kierujące się w swoim postępowaniu nie interesem osobistym, lecz dobrem całej zbiorowości. Dopiero połączenie tych dwóch aspektów - kwalifikacji merytorycznych oraz wysokiego poziomu moralnego - daje podstawę do legitymowania władzy w systemie merytokratcznym.

Formuła legitymizacyjna przyjęta $\mathrm{w}$ autorytarnej merytokracji może dawać mocne społeczne uznanie dla rządzących, lecz może też być jednocześnie piętą achillesową całego systemu. W pierwszym przypadku wzmocnieniu legitymacji służą niewątpliwe sukcesy gospodarcze oraz stale rosnący poziom życia obywateli, traktowane jako efekt działań władzy oraz jej długofalowej refleksyjnej polityki. Jednakże uzależnienie społecznego uznania od sukcesów gospodarczych może być zawodne, gdy sytuacja ekonomiczna się pogorszy — wówczas to władza zostaje obarczona winą za spadek poziomu życia obywatela. Należy zgodzić się z twierdzeniem Daniela Bella, że legitymowana merytokratycznie władza zwykle napotyka trzy problemy stopniowo podmywające jej społeczny autorytet $^{27}$. Po pierwsze, rodzi się problem izolowania się przedstawicieli elity od społeczeństwa oraz stopniowe zamykanie się uprzywilejowanej grupy przed napływem świeżej krwi. W wyniku tych procesów struktury społeczne z czasem kostnieją,

25 Problemy powstawania klanów rodowych w ramach KPCh przedstawił K. Brown, The New Emperors: Power and the Princelings in China, London 2014.

26 Więcej M. Bogusz, J. Jakubowski, op. cit., s. 46-48.

27 D.A. Bell, The China Model..., s. 111. 
społeczeństwo zaś rozwarstwia się ze względu na posiadane zasoby, a możliwość społecznego awansu zostaje stopniowo ograniczona ${ }^{28}$. Po drugie, izolacji elity towarzyszy pogarda dla osób spoza jej grona jako mniej refleksyjnych ${ }^{29}$ i jednocześnie wzrasta skłonność do nadużywania władzy do własnych celów utożsamianych $\mathrm{z}$ celami państwowymi ${ }^{30}$. Wreszcie, po trzecie, w wyniku nadużywania władzy przez rządzących następuje delegitymowanie całego systemu.

Delegitymacja następuje, ponieważ każdy przykład korupcji czy nepotyzmu w strukturach państwowych obala argumentację rządzących, że w strukturach władzy znajdują się właściwe osoby, a system premiuje jednostki najwybitniejsze i jednocześnie najbardziej moralne. Odwołanie do uzasadnienia merytokratycznego jako podstawy sprawowania władzy jest zbyt idealistyczne, przez co niemożliwe do zrealizowania $\mathrm{w}$ rzeczywistości społecznej, natomiast złożone obietnice rządów najlepszych osób w każdej chwili mogą być dosyć łatwo obalone przez wskazanie na fakty zaprzeczające oficjalnej narracji. Pod tym względem odporniejsze wydaje się uzasadnienie demokratyczne, gdyż w razie wyboru nieodpowiedniej osoby rządzący mogą uczynić współwinnymi temu wyborców jako mających ostateczne słowo przy urnie wyborczej. W systemie autorytarnym opartym na patriarchalnej relacji rządzących w stosunku do rządzonych cała wina za błędne wybory w obsadzaniu stanowisk państwowych spada na tych pierwszych. Wydaje się więc, że wieloletnie kampanie antykorupcyjne podejmowane przez KPCh zarówno w strukturach administracji państwowej, jak i partyjnych, które częstokroć kończą się surowymi wyrokami dotykającymi przedstawicieli samej partyjnej elity, wynikają nie tylko z rozgrywek frakcyjnych, lecz także z obaw o pozbawienie legitymacji systemu władzy ${ }^{31}$.

Omówione rozwiązania odwołujące się do narracji opartej na merytokracji mają kilka celów - po pierwsze, zapewnienie rzeczywistego dopływu do administracji siły fachowej zdolnej do sprawnego zarządzania państwem - a taka jest niezbędna, zważywszy na rozmach planów rozwoju gospodarczego Chin. Po

28 Podobne uwagi w stosunku do zachodniej narracji merytokratycznej wysuwa J. Litter, Against Meritocracy. Culture, power and myths of mobility, London-New York 2018, passim. Zob. też L.M. Alvarado, Dispelling the meritocracy myth: Lessons for higher education and student affairs educators, „The Vermont Connection” 31, 2010, s. 10-20; Ch. Hayes, Twilight of the Elites: America after Meritocracy, New York 2012; W. Deresiewicz, Excellent Sheep: The Miseducation of the American Elite and the Way to a Meaningful Life, New York 2014.

29 Problem ten jest uniwersalny dla merytokracji jako takiej — nie tylko we wschodnim wydaniu. Zob. M. Sandel, Tyrania merytokracji. Co się stato z dobrem wspólnym?, Warszawa 2020.

30 Według Davida Beethama w systemie legitymowanym merytokratycznie utożsamienia interesów elity z interesami państwa jest czymś naturalnym; idem, The Legitimation of Power, New York 1991.

31 Zdaniem D.A. Bella korupcja bardziej zagraża władzom chińskim niż działalność prodemokratycznych dysydentów. D.A. Bell, The China Model..., s. 114. Problem korupcji w Chinach omawia Y. Sun, Corruption and Market in Contemporary China, New York 2004; natomiast kampanie antykorupcyjne władz KPCh zob. A. Wedeman, Win, lose, or draw? China’s quarter century war on corruption, „Crime, Law and Social Change” 49, 2008, nr 1, s. 7-26. 
drugie, dają skuteczne narzędzia legitymujące władzę $-\mathrm{z}$ jednej strony przez skuteczność w podnoszeniu poziomu życia i dobrobytu obywateli, a z drugiej daje podstawę do uzasadnienia narracji, że państwem rządzą osoby najlepsze, cechujące się niezwykle wysokimi standardami moralnymi. Stanowią więc wygodne narządzie uzasadnienia władzy sprawowanej przez KPCh - według tej narracji składającej się z najbardziej kompetentnych i etycznych obywateli. Po trzecie zaś, tworzą pewnego rodzaju mit społeczny, że miejsce w hierarchii państwowej jest otwarte dla każdego obywatela, o ile ma niezbędny talent i podjął wysiłek, by uzyskać wykształcenie oraz podnosić swoje kwalifikacje. Odgrywają więc rolę zbliżoną do narracji american dream w USA, gdzie akcentuje się równą możliwość awansu społecznego uzależnionego od osobistych talentów i pracy. Co więcej, w razie niepowodzenia narracja merytokratyczna pozwala uzasadnić to winą jednostki i jej niewystarczającymi zdolnościami lub staraniami, a nie konstrukcją samego systemu władzy.

Zarysowany system autorytarnej merytokracji jest niewątpliwie oryginalnym produktem Chińczyków, wynikającym z tamtejszej tradycji patriarchalnych relacji społecznych, konfucjanizmu oraz kultu wiedzy i przygotowania fachowego. Należy zgodzić się zatem z tezą Bogdana Góralczyka, że nie jest możliwe przeniesienie w całości tego modelu do innych państw - opiera się bowiem na rozwiązaniach oraz filozofii typowej dla tamtejszego rejonu ${ }^{32}$. Nie jest jednak wykluczone kopiowanie pewnych rozwiązań zastosowanych w Państwie Środka, o ile w innych państwach zostaną uznane za będące podstawą sukcesu gospodarczego i tym samym warte naśladowania. Sukcesy gospodarcze azjatyckich autorytarnych merytokracji, w szczególności oszałamiający sukces modernizacyjny Chin, pokazuje, że istnieją inne drogi rozwoju niż zaproponowana przez Zachód, akcentująca konieczność powiązania systemu wolnorynkowego z ustrojem demokracji liberalnej opartej na prawach i wolnościach politycznych jednostki. Nawet więc jeśli w tej chwili Chińczycy nie traktują swojego modelu jako uniwersalnego ustroju społeczno-gospodarczego możliwego do zastosowania wszędzie na świecie — choć nie można wykluczyć tego w przyszłości — to jednak skutecznie podkopali pozycję hegemoniczną idei Zachodu, podważając ich roszczenie do uniwersalizmu i dziejowej konieczności. W wielu patriarchalnych społeczeństwach Azji czy Afryki to chińska droga może wydawać się atrakcyjniejsza niż propozycje Zachodu. Wreszcie system ten może jawić się jako o wiele skuteczniejszy w zakresie zarządzania życiem społecznym w porównaniu do zachodniego, zwłaszcza w sytuacjach nadzwyczajnych, wymagających natychmiastowej i stanowczej reakcji rządzących. Niejednokrotnie to azjatyckie autorytarne państwa pokazywane były jako przykład sprawnej i skutecznej walki z zagrożeniem epidemiologicznym związanym z COVID-19, stosujące metody, na jakie nie mogłyby sobie pozwolić demokracje zachodnie.

32 B. Góralczyk, op. cit., s. 12. 


\section{Bibliografia}

Alvarado L.M., Dispelling the meritocracy myth: Lessons for higher education and student affairs educators, „The Vermont Connection” 31, 2010.

Beetham D., The Legitimation of Power, New York 1991.

Bell D.A., The China Model. Political Meritocracy and the Limits of Democracy, New Jersey 2016.

Bell D.A., China's New Confucianism: Politics and Everyday Life in a Changing Society, Princeton-Oxford 2010.

Bell D.A., Introduction: The Theory, history, and practice of political meritocracy, [w:] The East Asian Challenge for Democracy. Political Meritocracy in Comparative Perspective, red. D.A. Bell, Ch. Li, New York 2013.

Bogusz M., Jakubowski J., Komunistyczna Partia Chin i jej państwo. Konserwatywny zwrot Xi Jinpinga, Warszawa 2019.

Brown K., The New Emperors: Power and the Princelings in China, London 2014.

Chou M., Moffit B., Bryant O., Political Meritocracy and Populism. Cure or Curse?, London 2019.

Deresiewicz W., Excellent Sheep: The Miseducation of the American Elite and the Way to a Meaningful Life, New York 2014.

Elman B.A., A Cultural History of Civil Examinations in Late Imperial China, Berkeley 2000.

Elman B.A., A Society in Motion: Unexpected consequences of political meritocracy in Late Imperial China, 1400-1900, [w:] The East Asian Challenge for Democracy. Political Meritocracy in Comparative Perspective, red. D.A. Bell, Ch. Li, New York 2013.

Fan R., Confucian meritocracy for contemporary China, [w:] The East Asian Challenge for Democracy. Political Meritocracy in Comparative Perspective, red. D.A. Bell, Ch. Li, New York 2013.

Fukuyama F., The End of History, „The National Interest” 1989, nr 16.

Fukuyama F., The End of History and The Last Man, New York 1992.

Gawlikowski K., Konfucjański model państwa w Chinach, Warszawa 2009.

Góralczyk B., Wielki renesans. Chińska transformacja i jej konsekwencje, Warszawa 2018.

Hayes Ch., Twilight of the Elites: America after Meritocracy, New York 2012.

Hitchcock D., Asian Values and the United States: How Much Conflict?, Washington 1994.

Kim C.H., Choi Y.B., How meritocracy is defined today?: Contemporary aspects of meritocracy, „Economics and Sociology” 10, 2017, nr 1.

Kim S.Y., Do Asian values exist? Empirical tests of the four dimensions of Asian values, „Journal of East Asian Studies" 10, 2010, nr 2.

Kurczewska J., Technokraci i ich świat społeczny, Warszawa 1997.

Kwang H.F., Fernandez W., Tan S., Lee Kuan Yew: The Man and His Ideas, Singapore 1998.

Lee E., Singapore: The Unexpected Nation, Singapore 2008.

Litter J., Against Meritocracy. Culture, power and myths of mobility, London-New York 2018.

Religa M., Mencjusz i Xunzi. O dobrym władcy, mędrcach i naturze ludzkiej, Warszawa 1999.

Sandel M., Tyrania merytokracji. Co się stało z dobrem wspólnym?, Warszawa 2020.

Shin D.Ch., How East Asians View Meritocracy: A Confucian Perspective, [w:] The East Asian Challenge for Democracy. Political Meritocracy in Comparative Perspective, red. D.A. Bell, Ch. Li, New York 2013.

Sławiński R., Konfucjanizm i jego współczesne interpretacje, Warszawa 2013.

Sun Y., Corruption and Market in Contemporary China, New York 2004.

Tan K.P., Meritocracy and elitism in a Global City: Ideological shifts in Singapore, „International Political Science Review” 29, 2008.

Tan K.P., Meritocracy and political liberalization in Singapore, [w:] The East Asian Challenge for Democracy. Political Meritocracy in Comparative Perspective, red. D.A. Bell, Ch. Li, New York 2013. 
Wedeman A., Win, Lose, or draw? China's quarter century war on corruption, „Crime, Law and Social Change" 49, 2008, nr 1.

Wong B., Political Meritocracy in Singapore: Lessons from the PAP Government, [w:] The East Asian Challenge for Democracy. Political Meritocracy in Comparative Perspective, red. D.A. Bell, Ch. Li, New York 2013.

Wójcik A.I., Konfucjusz, Kraków 1995.

Xiao H., Li Ch., China's Meritocratic Examinations and the Ideal of Virtuous Talents, [w:] The East Asian Challenge for Democracy. Political Meritocracy in Comparative Perspective, red. D.A. Bell, Ch. Li, New York 2013.

Yao X., Konfucjanizm. wprowadzenie, Kraków 2009.

Young M., The Rise of Meritocracy: 1870-2033, Harmondworth 1958.

Zhao D., The Confucian-legalist State: A New Theory of Chinese History, Oxford 2015. 